\title{
I-I3I mIBG Scintigraphy Curie Versus SIOPEN Scoring: Prognostic Value in Stage 4 Neuroblastoma
}

\author{
I-13I mIBG Sintigrafı Curie ve SIOPEN Skorlarının Evre 4 Nöroblastomada Prognostik \\ Değerinin Karşılaştııılması
}

- Saima Riazl, (1) Humayun Bashirl, (1) Saadiya Javed Khan2, (1) Abid Qazi3

IShaukat Khanum Memorial Cancer Hospital and Research Centre, Clinic of Nuclear Medicine, Lahore, Pakistan

2Shaukat Khanum Memorial Cancer Hospital and Research Centre, Clinic of Pediatric Oncology, Lahore, Pakistan

${ }^{3}$ Canal Bank, Clinic of Surgery, Lahore, Pakistan

\begin{abstract}
Objective: I-131 mIBG scan semi-quantitative analysis with modified Curie and the International Society of Pediatric Oncology Europe Neuroblastoma (SIOPEN) scoring systems is helpful in the evaluation of disease extent and has prognostic impact in stage 4 neuroblastoma.

Methods: Retrospective, cross-sectional analysis of baseline I-131 mIBG scans in 21 patients with stage 4 or 4 S neuroblastoma diagnosed between January 2007 and December 2015. All scans were assessed for Curie and SIOPEN scores. Distribution of scores was evaluated for risk factors i.e. age at diagnosis (>18 months) and early relapse (within 12 months). A curie score $<2$ and SIOPEN score $<4$ at diagnosis were correlated with event-free survival (EFS) and overall survival (OS).

Results: The data set comprised of $12(57 \%)$ males and $9(43 \%)$ females. Patients with age $>18$ months $(n=9)$ at diagnosis or early relapse $(n=9)$ had higher Curie [mean $5+7.5$ standard deviation (SD), $p=0.004$ ] and SIOPEN (mean 5.2+10.8 SD, $\mathrm{p}=0.02$ ) scores. Patients with a Curie score $<2$ and a SIOPEN score of $<4$ had better EFS and OS than patients with higher scores. Curie: 5 -year EFS $=$ Curie $<2(79 \%)$ versus Curie $>2(33 \%)(p=0.03)$; 5 -year OS=Curie $<2(56 \%)$ versus Curie $>2(36 \%)$ $(p=0.01)$. SIOPEN: 5 -year EFS=SIOPEN $<4$ (70\%) versus SIOPEN $>4(17 \%)(p=0.002)$; 5 -year OS=SIOPEN $<4(58 \%)$ versus SIOPEN $>4(17 \%)(p=0.04)$. There was no statistically significant difference between the two scoring systems in terms of survival predictive value (Hazard ratio $2.38,95 \% \mathrm{Cl}: 0.33-16.9, \mathrm{p}=0.38$ ).

Conclusion: I-131 mIBG Curie and SIOPEN scores have prognostication value in stage 4 neuroblastoma and should be routinely applied. Higher scores predict unfavorable prognosis.

Keywords: I-131 mIBG scan, neuroblastoma, Curie scores, SIOPEN scores
\end{abstract}

Öz

Amaç: I-131 mIBG sintigrafinin modifiye Curie ve International Society of Pediatric Oncology Europe Neuroblastoma (SIOPEN) skorlama sistemleri ile yarı-kantitatif analizi evre 4 nöroblastomda hastalığın yayılımını değerlendirmede yararlıdır ve prognostik etkisi bulunmaktadır.

Yöntem: Ocak 2007 ile Aralık 2015 tarihleri arasında, evre 4 veya 4S nöroblastom tanısıyla I-131 mIBG sintigrafi yapılmış 21 hastanın retrospektif, kesitsel analizi yapıldı. Tüm tetkikler Curie ve SIOPEN skoru ile değerlendirildi. Tanı yaşı (>18 ay) ve erken

Address for Correspondence: Saima Riaz MD, Shaukat Khanum Memorial Cancer Hospital and Research Centre, Clinic of Nuclear Medicine, Lahore, Pakistan Phone: +923465938557 E-mail: saimarz.dr@gmail.com Received: 05.05.2018 Accepted: 28.08.2018 
nüks (12 ay içinde) gibi risk faktörlerine göre skor dağılımı değerlendirildi. Tanı anında Curie skoru <2 ve SIOPEN skoru <4 hastalıksız (HGS) ve genel sağkalım (GS) ile ilişkili idi.

Bulgular: Çalışmaya 12 (57\%) erkek ve 9 (43\%) kadın dahil edildi. Tanı anında yaşı >18 ay olan hastalar ( $n=9)$ veya erken nüks edenlerde $(n=9)$ Curie [ortalama 5+7,5 standart deviasyon (SD), $p=0,004$ ] ve SIOPEN (ortalama 5,2+10,8 SD, $p=0,02$ ) skorları daha yüksek bulundu. Curie skoru <2 ve SIOPEN skoru <4 olan hastaların HGS ve GS daha yüksek skorlu hastalardan daha iyiydi. Curie: 5 -yll HGS=Curie $<2$ (\%79) vs Curie >2 (\%33) ( $p=0,03)$; 5-yll GS=Curie <2 (\%56) vs Curie >2 (\%36) ( $p=0,01)$. SIOPEN: 5-yll HGS=SIOPEN<4 (\%70) vs SIOPEN >4 (\%17) ( $p=0,002)$; 5 -yıl GS= SIOPEN <4 (\%58) vs SIOPEN >4 (\%17) $(p=0,04)$. Her iki skorlama sistemi arasında sağkalım öngörücü değer açıından istatistik olarak anlamlı farklılık saptanmadı (Risk oranı: 2,38, \%95 Cl: 0,33-16,9, p=0,38).

Sonuç: I-131 mIBG Curie ve SIOPEN skorlarının evre 4 nöroblastomda prognostik öngörü değeri vardır ve rutin olarak kullanılmalıdır. Yüksek skorlar daha kötü prognozu göstermektedir.

Anahtar kelimeler: I-131 mIBG sintigrafi, nöroblastoma, Curie skoru, SIOPEN skoru

\section{Introduction}

Neuroblastoma is the most common extra-cranial solid malignant tumor in children. It originates from the sympathetic nervous system, most frequently from the adrenal medulla. The heterogeneous clinical behavior of neuroblastoma is dependent on numerous clinical as well as biological features (1). Neuroblastoma is diagnosed over a wide age range, from birth through young adulthood. Older age at diagnosis indicates a grim survival. Poor prognostic factors include: Age >18 months, NMYC amplification, poorly differentiated, advanced stage disease, and indistinguishable tumor histology (2). Approximately $70 \%$ of neuroblastoma patients present with metastatic disease (3). With the current treatment approaches, age at diagnosis has proven to be one of the most influential predictors of the outcome. In patients older than 1 year, the 5-year disease-free survival rates for stage 4 neuroblastoma have been reported to be $30-46 \%$ (4).

Treatment regimens including induction therapy, autologous stem cell transplantation, better radiotherapy techniques and immunotherapy have led to improvements in diseasefree survival. Tailoring treatment to risk group stratification has improved outcome. The capacity to identify both biologic and clinical prognostic markers of response has the benefit of selecting treatment therapies (5).

Radioiodine labeled metaiodobenzylguanidine ( $\mathrm{mIBG)}$ is an aralkylguanidine, structurally parallel to norepinephrine. Almost $90 \%$ of neuroblastoma concentrate mIBG within the marrow, soft-tissue sites of disease or cortical bone $(6,7)$. Since $1-123$ labeled $\mathrm{mIBG}$ is not available in our part of the world, I-131 mIBG is used.

\section{Materials and Methods}

Retrospective data of baseline I-131 mIBG scans was analyzed in patients with stage 4 or 45 neuroblastoma registered between January 2007 and December 2015.
Our data set included 21 patients, aged 0.5 to 12 years. Twelve were males (57\%) and 9 (43\%) females.

This retrospective study has been approved by the Institutional Review Board of Shaukat Khanum Cancer Hospital and Research Centre, Lahore.

\section{Imaging}

Radiotracer dose in the range of 37 to $55 \mathrm{MBq}$ I-131 MIBG was injected intravenously adjusted to patients' weight according to EANM recommendations. Scanning was acquired at 24 and 48 hours using Siemens Symbia T16 camera, 128x128 matrix for planar scan, bed movement $7-8 \mathrm{~cm} / \mathrm{min}$.

\section{Semi-quantitative Analyses}

Semi-quantitative evaluation of all scans was performed using the Curie and International Society of Pediatric Oncology Europe Neuroblastoma (SIOPEN) scoring methodology.

Initially developed in 1995, scoring is based on the presence of mIBG uptake in multiple anatomic regions $(8,9)$. Ten different sites were scored, including 9 skeletal sites (head, chest, T-spine, L-spine, pelvis, upper arms, lower arms, femurs, and lower legs) and an additional tenth site for soft-tissue lesions.

The International Neuroblastoma Risk Group (INRG) Staging System (INRGSS) is an imaging defined staging and risk assessment system. According to the SIOPEN semiquantitative scoring method, the skeleton was divided into 12 anatomical body segments as follows: the skull, the thoracic cage, the proximal right upper limb, the distal right upper limb, the proximal left upper limb, the distal left upper limb, the spine, the pelvis, the proximal right lower limb, the distal right lower limb, the proximal left lower limb and the distal left lower limb. The extent and pattern of skeletal mIBG involvement was scored using a 0-6 scale to discriminate between focal discrete lesions and patterns of more diffuse infiltration (10). 
Distribution of scores was evaluated for two risk factors i.e. age at diagnosis (>18 months) and early relapse (within 12 months).

\section{Statistical Analysis}

The data were analyzed by the Kaplan-Meier method using IBM SPSS statistics 20 program. A Curie score $<2$ and SIOPEN score $<4$ (est defined cut-off) at diagnosis were correlated with event-free survival (EFS) and overall survival (OS) (11). Log-rank test with a $p$ value of less than 0.05 was used to evaluate the differences between groups. Cox proportional hazards regression model applying the enter method was used to estimate hazards ratio (HR) for analysis.

\section{Results}

The data set included 12 (57\%) males and 9 (43\%) females (age range: 4 months to 12 years). All had stage 4 disease in terms of osteomedullary metastases $(n=9)$, soft issue metastases $(n=8)$ and cytological bone marrow involvement $(\mathrm{n}=4)$ (Table 1).

Out of total 21 patients, 12 (57\%) were younger than 18 months, while $9(43 \%)$ older than 18 months of age. Nine patients (57\%) had either relapse within 12 months after diagnosis or primary progressive disease.

\section{Semi-quantitative Scoring}

Overall Curie score ranged from minimum 1 to a maximum score of 27 (average 5.9 $\pm 7.9 \mathrm{~S}$ ). SIOPEN scores ranged between 0 to a maximum score of 48 [average $6.1 \pm 11.6$ standard deviation (SD)].

On Curie scores analysis, 10 patients had $<2$ and 11 had $>2$ Curie scores. SIOPEN score $<4$ was calculated in 15 and $>4$ in 6 patients.

\section{Distribution of mIBG Score by Risk Factors}

In patients with age $<18$ months at diagnosis, Curie scores

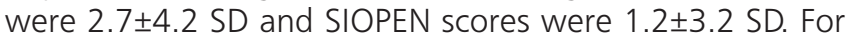
age $>18$ months, Curie scores were identified as $10.4 \pm 9.7$ SD and SIOPEN scores $12.8 \pm 15.4$ SD. On bivariate analysis, the scores were higher in age $>18$ months $(p=0.002$ for Curie and $p=0.018$ for SIOPEN scores).

In reference to relapse, patients with early relapse had Curies

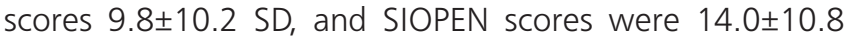

Table 1. Patient and disease characteristics

\begin{tabular}{ll}
\hline $\mathbf{n = 2 1}$ & \\
\hline Gender & $12(57 \%)$ males \\
& $9(43 \%)$ females \\
Age & Average: 2.7 years \\
& Range: 4 months to 12 years \\
Disease characteristics & $\begin{array}{l}\text { Osteomedullary metastases: } 9 \\
\text { Soft tissue metastases: } 8 \\
\\
\end{array}$ \\
& Cytological bone marrow: 4
\end{tabular}

SD. In comparison to this, patients who did not show early relapse, the Curie scores were $1.2 \pm 1.5$ SD, while SIOPEN scores were 3.6 \pm 1.6 SD. The scores tended to be higher in patients with early relapse within 12 months in comparison to patients who did not show early relapse $(p=0.004$ for Curie and $p=0.02$ for SIOPEN scores). The details of these scores have been displayed in Figure 1.

\section{Disease Outcome and Survival Analysis}

Out of 10 patients with Curie score $<2,2(20 \%)$ relapsed and $2(20 \%)$ died, while with Curie score $>2,7$ out of 11 $(63.6 \%)$ relapsed and $6(54.5 \%)$ died.

On analysis of SIOPEN scores, out of 15 patients with score $<4,4(27 \%)$ relapsed and $4(27 \%)$ died, while with scores $>4,5$ out of $6(83 \%)$ relapsed and $4(67 \%)$ died.

Comparative analyses demonstrated that Curie score $<2$ and a SIOPEN score of $<4$, respectively, had better EFS and OS than patients with higher scores. 5-years EFS for Curie score $<2$ was $79 \%$ versus $33 \%$ for score $>2(p=0.03)$. 5 -year OS was $56 \%$ for Curie score $<2$ versus 36\% for score $>2$ $(\mathrm{p}=0.01)$.

Based on SIOPEN scoring, 5-year EFS was found to be $70 \%$ for score $<4$ as compared to $17 \%$ for score $>4(p=0.002)$. Similarly, 5 -year OS for score $<5$ was $58 \%$ versus $17 \%$ for score $>4(p=0.04)$. The Kaplan-Meier disease-free survival

\begin{tabular}{|c|c|c|}
\hline & Curie score & SIOPEN Score \\
\hline \multicolumn{3}{|c|}{ Age at Diagnosis } \\
\hline$<18$ months & $2.7-\mathrm{SD} 4.2{ }_{\mathrm{P}=0.02}$ & $1.2-\mathrm{SD} 3.2]_{\mathrm{P}=\mathbf{0 . 0 1 8}}$ \\
\hline >18 months & $10.4-$ SD9.7] & $12.8-S D$ 15.4 \\
\hline \multicolumn{3}{|c|}{ Tumor Relapse within 12 months } \\
\hline No & $1.2-S D 1.5$ & $3.6-\mathrm{SD} 1.6] \mathrm{P}=\mathbf{0 . 0 2}$ \\
\hline Yes & $9.8-S D 10.2$ J & $14.0-$ SD 10.8 \\
\hline
\end{tabular}

Figure 1. Distribution of Curie and International Society of Pediatric Oncology Europe Neuroblastoma scores with reference to risk factors SD: Standard deviation
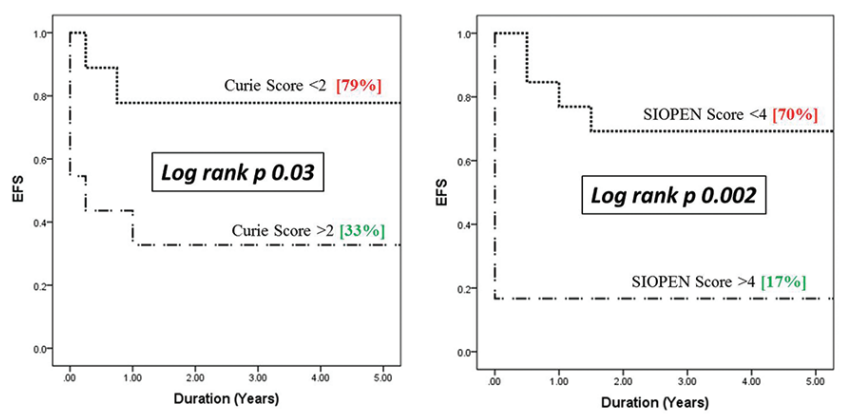

Figure 2. Curie and International Society of Pediatric Oncology Europe Neuroblastoma scores at diagnosis and event-free survival SIOPEN: International Society of Pediatric Oncology Europe Neuroblastoma, EFS: Event-free survival 
distributions based on these low or high Curie and SIPOEN scores were significantly different (Figure 2, 3).

\section{Comparing Curie and SIOPEN Scoring Systems in Predicting Prognosis}

On bivariate analysis, there was no statistically significant difference between the two scoring systems in terms of survival predictive value [HR: $2.38,95 \%$ confidence interval $(\mathrm{Cl})$ : 0.33-16.9, $\mathrm{p}=0.38]$.

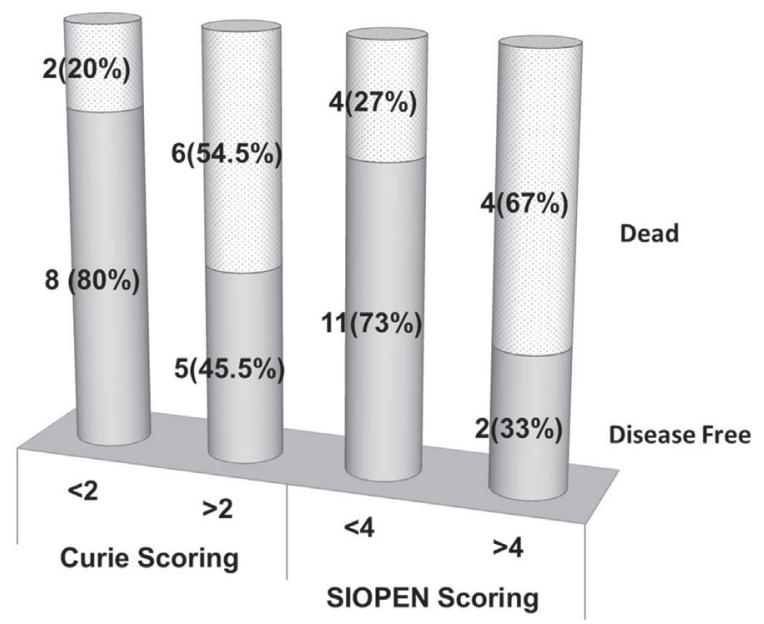

Figure 3. Curie and International Society of Pediatric Oncology Europe Neuroblastoma scores at diagnosis and overall survival

SIOPEN: International Society of Pediatric Oncology Europe Neuroblastoma

\section{Discussion}

Accurate disease staging is essential for an optimized treatment plan. The outcome is related to disease extent in stage 4 neuroblastoma. Radioiodine labeled mIBG semi -quantitative scoring systems are used to estimate diasease burden. We selected two poor prognostic factors, age older than 18 months and early relapse, to evaluate the validity of mIBG scores (12).

In most of the earlier studies, age $<12$ months has been taken as the poor prognostic indicator. However, as shown by Moroz et al. $(12,13), 18$ months is a powerful indicat or of unfavorable outcome as the cut off for age-of-diagnosis. Likewise, time to first relapse influences survival. London et al. (13), demonstrated that mortality risk is higher in patients who relapse early (14).

Scores tended to be higher in patients with age $>18$ months at diagnosis and early relapse. We found a statistically significant positive correlation between higher scores and poor prognostic factors. In this regard, radioiodine mIBG scan at baseline with high scores can be taken as an indicator of poor outcome. Various studies have shown different cut-off values for mIBG score systems $(14,15)$, and there are several previous studies where no significant prognostic impact of the initial mIBG score was reported $(16,17)$.

However, Decarolis et al. (11), reported the best cut-off for the Curie score as 2 and that for the SIOPEN score as 4 , which significantly discriminated between poor and more favorable outcomes. We evaluated the validity of these cutoff scores in our referral group. Patients who tended to have higher scores at baseline had higher frequencies of disease relapse and deaths. Outcome was significantly better in lower scores with better EFS and OS when compared with higher scores.

An INRG task force led by Matthay et al. (10) has examined both methodologies as a potential prognostic marker for outcome determination. The SIOPEN scoring methodology is currently being used in SIOPEN high risk neuroblastoma trials, with Curie scoring used in COG trials.

In a prior review of COG-A3973, COG investigators were unable to identify a mIBG (Curie) score at diagnosis that correlated with outcome (14). Ladenstein et al. (15) studied the baseline scores at diagnosis and reported SIOPEN mIBG score to be highly prognostic of outcome in two independent data sets, SIOPEN/HR-NBL1 and COG-A3973. In comparison, our data set comply with findings of Decarolis et al. (11). We found that the prognostic value of Curie and SIOPEN scores were similar. Although SIOPEN scores do not include soft tissue disease, both scoring systems were found to have similar prognostic significance with no statistically significant difference (HR: 2.38, 95\% Cl: 0.33-16.9, $\mathrm{p}=0.38$ ).

\section{Study Limitation}

The limitation of this study is the limited number of followup I-131 mIBG scans, to provide statistically significant outcome analyses based on post-induction Curie and SIOPEN scores. Our data needs further extension with future prospect to report the validity of these scores in therapeutic response evaluation and to develop mIBG scoring systems based response criteria.

\section{Conclusion}

In conclusion, our study demonstrates the feasibility of mIBG scoring systems, which have prognostication value in stage 4 neuroblastoma. These scores are not used in routine clinical practice. However, with advancement in therapeutic options in stage 4 neuroblastoma, the implementation of mIBG scoring systems can be helpful in more precise prognostication based treatment.

\section{Ethics}

Ethics Committee Approval: The study was approved by Institutional Review Board Shaukat Khanum Memorial Cancer Hospital and Research Centre, Lahore, Pakistan.

Informed Consent: Consent form has been filled out by all authors. 
Peer-review: Externally peer-reviewed.

\section{Authorship Contributions}

Surgical and Medical Practices: S.J.K., A.Q., Concept: S.R., Design: S.R., Data Collection or Processing: S.R., Analysis or Interpretation: S.R., Literature Search: S.R., H.B., Writing: S.R.

Conflict of Interest: No conflict of interest was declared by the authors.

Financial Disclosure: The authors declared that this study received no financial support.

\section{References}

1. Matthay KK, Villablanca JG, Seeger RC, Stram DO, Harris RE, Ramsay NK, Swift P, Shimada H, Black CT, Brodeur GM, Gerbing RB, Reynolds CP. Treatment of high-risk neuroblastoma with intensive chemotherapy, radiotherapy, autologous bone marrow transplantation, and 13-cis-retinoic acid. Children's Cancer Group. N Engl J Med 1999;341:1165-1173.

2. Cheung NK, Zhang J, Lu C, Parker M, Bahrami A, Tickoo SK, Heguy A, Pappo AS, Federico S, Dalton J, Cheung IY, Ding L, Fulton R, Wang J, Chen X, Becksfort J, Wu J, Billups CA, Ellison D, Mardis ER, Wilson RK, Downing JR, Dyer MA; St Jude Children's Research Hospital-Washington University Pediatric Cancer Genome Project. Association of age at diagnosis and genetic mutations in patients with neuroblastoma. JAMA 2012;307:1062-1071.

3. Moroz V, Machin D, Faldum A, Hero B, lehara T, Mosseri V, Ladenstein R, De Bernardi B, Rubie H, Berthold F, Matthay KK, Monclair T, Ambros PF, Pearson AD, Cohn SL, London WB. Changes over three decades in outcome and the prognostic influence of age-at-diagnosis in young patients with neuroblastoma: a report from the International Neuroblastoma Risk Group Project. Eur J Cancer 2011;47:561-571.

4. Kreissman SG, Villablanca JG, Diller L, London WB, Maris JM, Park JR, Reynolds CP, Allmen DV, Cohn SL, Matthay KK. Response and toxicity to a doseintensive multi-agent chemotherapy induction regimen for high risk neuroblastoma (HR-NB): a Children's Oncology Group (COG A3973) study. J Clin Oncol 2007;25:9505.

5. Yu AL, Gilman AL, Ozkaynak MF, London WB, Kreissman SG, Chen HX, Smith M, Anderson B, Villablanca JG, Matthay KK, Shimada $H$, Grupp SA, Seeger R, Reynolds CP, Buxton A, Reisfeld RA, Gillies SD, Cohn SL, Maris JM, Sondel PM; Children's Oncology Group. Anti-GD2 antibody with GM-CSF, interleukin-2, and isotretinoin for neuroblastoma. N Engl J Med 2010;363:1324-1334.

6. Wieland DM, Mangner TJ, Inbasekaran MN, Brown LE, Wu JL. Adrenal medulla imaging agents: a structure-distribution relationship study of radiolabeled aralkylguanidines. J Med Chem 1984;27:149155.

7. Claudiani F, Stimamiglio P, Bertolazzi L, Cabria M, Conte $M$, Villavecchia GP, Garaventa A, Lanino E, De Bernardi B, Scopinaro G. Radioiodinated meta-iodobenzylguanidine in the diagnosis of childhood neuroblastoma. Q J Nucl Med 1995;39(Suppl 4):21-24.
8. Ady N, Zucker JM, Asselain B, Edeline V, Bonnin F, Michon J, Gongora R, Manil L. A new 123I-MIBG whole body scan scoring method: application to the prediction of the response of metastases to induction chemotherapy in stage IV neuroblastoma. Eur J Cancer 1995;31:256-261.

9. Matthay KK, Edeline V, Lumbroso J, Tanguy ML, Asselain B, Zucker JM, Valteau-Couanet D, Hartmann O, Michon J. Correlation of early metastatic response by 1231 -metaiodobenzylguanidine scintigraphy with overall response and event-free survival in stage IV neuroblastoma. J Clin Oncol 2003;21:2486-2491.

10. Matthay KK, Shulkin B, Ladenstein R, Michon J, Giammarile F, Lewington V, Pearson AD, Cohn SL. Criteria for evaluation of disease extent by (123)I-metaiodobenzylguanidine scans in neuroblastoma: a report for the International Neuroblastoma Risk Group (INRG) Task Force. Br J Cancer 2010;102:1319-1326.

11. Decarolis B, Schneider C, Hero B, Simon T, Volland R, Roels F, Dietlein M, Berthold F, Schmidt M. Iodine-123 metaiodobenzylguanidine scintigraphy scoring allows prediction of outcome in patients with stage 4 neuroblastoma: results of the Cologne interscore comparison study. J Clin Oncol 2013:31:944-951.

12. Moroz $V$, Machin $D$, Faldum $A$, Hero B, lehara T, Mosseri $V$, Ladenstein R, De Bernardi B, Rubie H, Berthold F, Matthay KK, Monclair T, Ambros PF, Pearson AD, Cohn SL, London WB. Changes over three decades in outcome and the prognostic influence of age-at-diagnosis in young patients with neuroblastoma: a report from the International Neuroblastoma Risk Group Project. Eur J Cancer 2011;47:561-571.

13. London WB, Castel V, Monclair T, Ambros PF, Pearson AD, Cohn SL, Berthold F, Nakagawara A, Ladenstein RL, lehara T, Matthay KK. Clinical and biologic features predictive of survival after relapse of neuroblastoma: a report from the International Neuroblastoma Risk Group project. J Clin Oncol 2011;29:3286-3292.

14. Yanik GA, Parisi MT, Shulkin BL, Naranjo A, Kreissman SG, London WB, Villablanca JG, Maris JM, Park JR, Cohn SL, McGrady P, Matthay KK. Semiquantitative mIBG scoring as a prognostic indicator in patients with stage 4 neuroblastoma: a report from the Children's oncology group. J Nucl Med 2013;54:541-548.

15. Ladenstein R, Lambert B, Pötschger U, Castellani MR, Lewington V, Bar-Sever Z, Oudoux A, Śliwińska A, Taborska K, Biassoni L, Yanik GA Naranjo A, Parisi MT, Shulkin BL, Nadel H, Gelfand MJ, Matthay KK, Park JR, Kreissman SG, Valteau-Couanet D, Boubaker A. Validation of the mIBG skeletal SIOPEN scoring method in two independent high-risk neuroblastoma populations: the SIOPEN/HR-NBL1 and COG-A3973 trials. Eur J Nucl Med Mol Imaging 2018;45:292-305.

16. Katzenstein HM, Cohn SL, Shore RM, Bardo DM, Haut PR, Olszewski M, Schmoldt J, Liu D, Rademaker AW, Kletzel M. Scintigraphic response by 1231 -metaiodobenzylguanidine scan correlates with event-free survival in high-risk neuroblastoma. J Clin Oncol 2004;22:3909-3915.

17. Messina JA, Cheng SC, Franc BL, Charron M, Shulkin B, To B, Maris JM, Yanik G, Hawkins RA, Matthay KK. Evaluation of semiquantitative scoring system for metaiodobenzylguanidine (mIBG) scans in patients with relapsed neuroblastoma. Pediatr Blood Cancer 2006;47:865-874. 